\title{
PENERAPAN MODEL CONTEXTUAL TEACHING AND LEARNING (CTL) SE- BAGAI UPAYA UNTUK MENINGKATKAN HASIL BELAJAR DAN KINERJA ILMIAH FISIKA SISWA
}

\author{
Gede Yohanes Arygunartha \\ Jurusan Ilmu Administrasi Negara \\ Fakultas Ilmu Sosial dan Ilmu Politik, Universitas Mahendradatta \\ Jl. Ken Arok No. 12, Peguyangan Denasar \\ E-mail:Anez_ary25@gmail.com
}

\begin{abstract}
Abstrak - Penelitian ini bertujuan untuk meningkatkan hasil belajar dan kinerja ilmiah fisika siswa. Penelitian ini merupakan penelitian tindakan kelas (classroom action research). Subjek dari penelitian ini adalah siswa kelas XI TKB 2 SMK Negeri 3 Singaraja pada semester ganjil tahun pelajaran 2013/2014 sebanyak 19 orang siswa laki-laki. Penelitian ini dilaksanakan dalam dua siklus dengan masing-masing tahapan siklus terdiri dari perencanaan, tindakan, observasi/evaluasi, dan refleksi. Hasil penelitian ini menunjukkan bahwa 1) terjadi peningkatan kinerja ilmiah siswa. Pada siklus I nilai rata-rata kinerja ilmiah yang dicapai siswa adalah 77,37 dengan kategori cukup tinggi, sedangkan pada siklus II meningkat menjadi 87,90 dengan kategori sangat tinggi, 2) terjadi peningkatan hasil belajar fisika siswa. Pada siklus I nilai rata-rata hasil belajar fisika yang dicapai siswa adalah 73,00 sedangkan pada siklus II meningkat menjadi 77,50. Penelitian tindakan kelas ini dikategorikan berhasil karena telah mencapai tingkat ketuntasan klaksikal sebesar 94,7\%
\end{abstract}

Kata-kata kunci : model pembelajaran contextual teaching and learning, hasil belajar, kinerja ilmiah

\begin{abstract}
This study aimed at improving learning outcomes and performance of physical science students. This study was an action research (classroom action research). The subject at this study was the eleventh grade of TKB 2 students of SMKN 3 Singaraja in the semester of academic year 2013/2014 which consisted of 19 male students. This study was conducted in two cycles with each cycle phase was planning, action, observation/evaluation, and reflection. The results of this study indicates that 1) There is an increase in scientific performance of students where in the first cycle, the average value of scientific performance achieved by students is 77.37 with a high enough category, and in the second cycle it increases to 87.90 which is categorized as high category; 2) There is an increase in student learning outcomes physics where in the first cycle, the average value of the results achieved by students studying physics that is 73.00 while is the second cycle increased to 77.50. Classroom action research is considered successful because it has reached the level of $94.7 \%$ completeness classical.
\end{abstract}

Keywords : Learning model of contextual teaching and learning, learning outcomes, performance scientific

\section{PENDAHULUAN}

Pendidikan berfungsi untuk menciptakan perubahan ke arah kehidupan yang lebih inovatif (Suastra et al., 2005). Pendidikan tidak hanya sebagai salah satu alat yang digunakan untuk mengembangkan pengetahuan di sekolah, tetapi juga digunakan sebagai aspek pendidikan. Salah satu aspek pendidikan yang digunakan di era globalisasi pada saat ini adalah pembelajaran PAIKEM. PAIKEM adalah singkatan dari Pembelajaran Aktif, Inovatif, Kreatif, Efektif dan Menyenangkan. Menurut Permendiknas No 41 Tahun 2007 tentang standar proses juga diamanatkan bahwa dalam kegiatan inti pembelajaran harus dilakukan secara interaktif, inspirat- 
if, menyenangkan, menantang, memotivasi peserta didik untuk berpartisipasi aktif, serta memberikan ruang yang cukup bagi kreativitas dan kemandirian sesuai dengan bakat, minat dan perkembangan fisik dan psikologis peserta didik. Berbagai studi yang mengarah pada peningkatan efisiensi, efektivitas layanan dan pengembangan sebagai konsekuensi dari suatu inovasi pendidikan sudah dilakukan dalam implementasi kurikulum (Mulyasa, 2006).

Menurut Santyasa (2006), pendidikan adalah untuk menyiapkan generasi muda yang tidak semata hanya memperoleh data, informasi, dan pengetahuan, tetapi yang lebih penting adalah mengkonstruksi pemahaman (understanding), menumbuhkan wawasan (insight), dan mengembangkan kearifan (wisdom).

Hasil observasi awal penulis di SMK Negeri 3 Singaraja di mana hasil belajar dan kinerja ilmiah siswa didapatkan dari data hasil wawancara, observasi dan dokumentasi. Hasil observasi peneliti terhadap siswa dalam pembelajaran di kelas dapat disimpulkan sebagai berikut yaitu Pertama, seorang guru sudah melibatkan siswa ketika mengikuti pembelajaran di kelas, tetapi dalam hal ini para siswa yang masih kurang aktif dalam mengikuti pembelajaran di kelas. Keadaan ini yang membuat siswa hanya sebagai pendengar saja dalam melaksanakan proses belajar mengajar, dan hal yang lebih buruk lagi siswa tersebut hanya mencatat-catat saja ketika diberikan penjelasan tentang materi pelajaran. Guru juga lebih sering menggunakan LKS, modul atau sumber-sumber buku lainnya sebagai patokan dalam mengajar, dan memberikan rumus-rumus sesuai dengan materi ajar kemudian latihan soal yang terdapat dalam modul tersebut. Keadaan ini yang menyebabkan siswa tidak bisa merespon dengan baik atau menangkap pelajaran yang diberikan ketika guru memberikan konsep materi pembelajaran. Kedua, model pembelajaran yang dilakukan masih sangat konvensional terlihat dari hasil data diatas yang menunjukan model sehingga siswa tersebut merasa bosan dan jenuh ketika mengikuti pembelajaran yang dilakukan oleh seorang guru di kelas. Model pembelajaran konvensional yang dilakukan oleh seorang guru ketika mengajar di kelas membuat siswa kurang aktif dalam mengikuti pembelajaran yang diberikan oleh guru. Siswa hanya menjadi pendengar saja ketika diberikan penjelasan oleh guru. Pembelajaran yang dilakukan sebaiknya menfokuskan atau mengarahkan siswanya ke materi pelajaran yang dibahas pada pertemuan awal pelajaran, dengan mengaitkan materi demi materi yang diberikan terkait dengan konteks sosial dan budaya yaitu fenomena fisika dalam kehidupan sehari-hari. Ketiga, pengelolaan di dalam kelas yang masih sangat kurang. Ini dikarenakan guru jarang mengajak siswa menerapkan pembelajaran kooperatif di kelas. Pembelajaran kooperatif ini dimaksudkan untuk membentuk kelompok belajar yang bersifat heterogen berdasarkan jenis kelamin dan kemampuan belajar siswa. Hal ini mengakibatkan siswa merasa bahwa dirinya diperlakukan secara adil. Artinya, tidak ada jarak pemisah antara siswa yang memiliki kemampuan rendah, sedang maupun tinggi. Kelompok belajar yang dibentuk akan memperbesar peluang siswa untuk menambah pengetahuannya menjadi lebih besar karena siswa akan mudah berdiskusi di dalam kelompoknya atau antar kelompok.

Dari nilai hasil observasi yang telah dilakukan, peneliti mengangkat materi dalam dua siklus. Untuk materi fisika yang diajarkan dalam siklus I adalah fluida sedangkan untuk siklus II adalah suhu dan kalor. Kompetensi yang harus dicapai dalam materi fluida ini adalah siswa dapat memahami hukum-hukum yang dapat berhubungan dengan fluida statik dan dinamik. Namun, dalam penyampaian materi fluida ini, masih banyak siswa yang belum mencapai standar ketuntasan yang diharapkan, dan ketercapaian hasil belajar siswa masih belum bisa dikatakan optimal. Faktor-faktor yang menyebabkan banyak siswa mendapatkan nilai di bawah KKM adalah pembelajaran yang dilakukan oleh guru masih bersifat konvensional, pengajaran di kelas masih menggunakan papan tulis dan spiudol sehingga pembelajaran fisika masih terlihat kurang menarik perhatian siswa dan menyebabkan nilai hasil belajar dan kinerja ilmiah siswa belum mencapai standar yang diharapkan karena siswa belum terbiasa dengan model CTL. Sedangkan untuk siklus II, kompetensi yang harus dicapai dalam materi suhu dan kalor adalah memahami konsep suhu dan kalor, dalam pencapaian kompetensi ini 
siswa sudah mulai terbiasa dengan model CTL sehingga, dapat dibuktikan dari nilai hasil belajar dan kinerja ilmiah yang mengalami peningkatan dari siklus I ke siklus II. Adanya peningkatan hasil belajar dan kinerja ilmiah tersebut karena siswa sudah mulai terbiasa dengan model CTL, karena model CTL ini mendorong siswa untuk bisa menemukan sendiri materi dan membuat hubungan antara pengetahuan yang dimilikinya.

Pembelajaran kontekstual adalah konsep belajar yang membantu guru menghubungkan antara materi pelajaran yang dikaitkan dengan situasi dunia nyata siswa dan mendorong siswa membuat hubungan antara pengetahuan yang dimlikinya dengan penerapannya dalam kehidupan sehari-hari (Johnson, 2011). Pembelajaran kontekstual merupakan suatu konsep belajar yang membantu guru mengaitkan materi yang diajarkannya dengan situasi dunia nyata siswa dan mendorong siswa membuat hubungan antara pengetahuan yang dimilikinya dengan penerapannya dalam kehidupan mereka sebagai anggota keluarga dan masyarakat

Penelitian ini bertujuan untuk meningkatkan hasil belajar dan kinerja ilmiah fisika siswa dengan menggunakan model pembelajaran Contextual Teaching And Learning (CTL).

\section{METODE PENELITIAN}

Jenis penelitian ini adalah penelitian tindakan kelas (classroom action research). Subyek dari penelitian tindakan kelas ini adalah semua siswa kelas XI TKB 2 SMK Negeri 3 Singaraja tahun pelajaran 2013/2014, yang berjumlah 19 siswa, yang terdiri dari siswa laki-laki saja dan tidak ada siswa perempuan. Obyek dari penelitian ini adalah hasil belajar siswa, kinerja ilmiah siswa, tanggapan siswa dan model pembelajaran Contextual Teaching And Learning.

Subyek dari penelitian tindakan kelas ini adalah semua siswa kelas XI TKB 2 SMK Negeri 3 Singaraja tahun pelajaran 2013/2014, yang berjumlah 19 siswa, yang terdiri dari siswa laki-laki saja dan tidak ada siswa perempuan. Alasan pengambilan subjek di kelas XI TKB (Teknik Kontruksi Bangunan) 2 karena berdasarkan hasil observasi menunjukkan masih rendahnya ha- sil belajar dan kinerja ilmiah fisika siswa kelas XI TKB 2 di SMK Negeri 3 Singaraja.

Penelitian tindakan kelas ini dirancang terdiri dari dua siklus, diharapkan dengan dua siklus hasil belajar dan kinerja ilmiah mencapai $75 \%$, jika dalam dua siklus tidak mencapai tingkat ketuntasan $75 \%$, maka dilanjutkan dengan siklus III begitu seterusnya sehingga mencapai tingkat ketuntasan $75 \%$. Dalam setiap siklus dibagi menjadi 4 tahap kegiatan yaitu, (1) Perencanaan Tindakan, (2) Pelaksanaan Tindakan, (3) Observasi/Evaluasi, dan (4) Refleksi.

Hasil belajar siswa kelas XI TKB 2 SMK Negeri 3 Singaraja pada pembelajaran Fisika sebagian besar belum maksimal, dalam menyelesaikan permasalahan yang terkait dengan materi pembelajaran yang sebenarnya, yakni kesenjangan antara hasil belajar dan kinerja ilmiah siswa di bidang fisika. Hal ini menggugah keinginan peneliti untuk menyelidiki lebih jauh akar permasalahan yang dialami siswa kelas XI TKB 2 SMK Negeri 3 Singaraja. Penelitian ini sekaligus menjadi langkah awal penelitian tindakan kelas yang akan dilakukan.

Peneliti terlebih dahulu mengadakan observasi ke sekolah dan melakukan wawancara langsung dengan guru fisika di kelas XI TKB 2 SMK Negeri 3 Singaraja pada tahun pelajaran 2013/2014. Kegiatan ini dilaksanakan beberapa kali dari tanggal 24 Juli sampai 29 Juli 2013 untuk mengungkap permasalahan yang dialami oleh guru maupun siswa kelas XI TKB 2 SMK Negeri 3 Singaraja terkait dengan pembelajaran fisika. Hasilnya, peneliti bersama dengan guru fisika berhasil mengungkap bahwa motivasi siswa yang mencakup hasil belajar dan kinerja ilmiah siswa dalam proses pembelajaran fisika masih tergolong rendah terlihat dari rincian hasil belajar siswa memperoleh rata-rata nilai sebesar 67,5 dan kinerja ilmiah sebesar 68,4 dengan kategori cukup tinggi.

Secara keseluruhan, hasil dari kegiatan permasalahan ini menjadi hasil refleksi awal penelitian tindakan kelas yang dilaksanakan di kelas XI TKB 2 SMK Negeri 3 Singaraja pada tahun pelajaran 2013/2014. Berdasarkan hasil observasi awal yang dilakukan di SMK Negeri 3 Singaraja, peneliti mempersiapkan segala sesuatu 
hal yang diperlukan dalam melaksanakan penelitian yang dilakukan, dengan topik untuk pertemuan pertama adalah materi fisika tentang fluida yang terbagi menjadi 5 kali pertemuan dalam setiap pembelajaran dan begitu juga yang dilakukan untuk tes akhir siklus.

Sesuai dengan siklus yang dijelaskan pada gambar 3.1 maka adapun tahapan-tahapan pelaksanaan penelitian tindakan ini adalah sebagai berikut:

\section{Tahap Perencanaan Tindakan Siklus I}

Tahapan ini disusun berdasarkan rancangan tindakan sebagai pedoman dalam melaksanaan tindakan. Tindakan tersebut adalah sebagai berikut :

a) Peneliti mensosialisasikan pembelajaran kontekstual kepada guru mata pelajaran sebelum proses pembelajaran dimulai.

b) Menjabarkan materi pembelajaran menjadi sub-sub materi sesuai dengan pedoman kurikulum tingkat satuan pendidikan (KTSP) dan silabus kelas XI SMK Negeri 3 Singaraja.

c) Merumuskan indikator hasil belajar, sebagai pembatas tentang apa yang diharapkan, sehingga dapat dipahami siswa setelah mengikuti pembelajaran yang didasarkan pada standar kompetensi mata pelajaran fisika.

d) Menyusun rencana pelaksanaan pembelajaran (RPP) untuk siklus I dengan pokok bahasan fluida yang terdiri atas 4 RPP.

e) Merancang instrumen perangkat pembelajaran seperti lembar kerja siswa (LKS) Individu, LKS Praktikum, lembar observasi dan angket tanggapan siswa.

f) Membentuk kelompok siswa yang beranggotakan 4-5 orang. Pada masing-masing kelompok ditentukan ada ketua kelompok.

g) Menyiapkan kunci jawaban semua tes yang akan digunakan dalam penilaian serta dalam rangka memberikan umpan balik secara terstruktur.

\section{Tahap Pelaksanaan Tindakan Siklus I}

Pada proses pelaksanaan tindakan ini, melibatkan peran guru dalam penyediaan waktu dan kesempatan kepada peneliti dalam menerapkan model belajar kontekstual di kelas. Tindakan pada siklus I dilaksanakan dalam 5 kali pertemuan.

\section{Pertemuan I}

Untuk pertemuan I siklus I, Materi yang disampaikan adalah Tekanan dan Hukum Archimedes pada RPP 01 Siklus I yang tersedia pada Lampiran $\overline{03}$. Kegiatan ini dilakukan selama 2 jam pelajaran (JP) yaitu 90 menit, dengan pembagian waktu yaitu 60 menit teori dan 30 menit praktikum.

\section{Pertemuan II}

Untuk pertemuan II siklus I, Materi yang disampaikan adalah Hukum Pascal pada RPP_02 Siklus I yang tersedia pada Lampiran 04. Kegiatan ini dilakukan selama 2 jam pelajaran (JP) yaitu 90 menit, dengan pembagian waktu yaitu 60 menit teori dan 30 menit praktikum .

\section{Pertemuan III}

Untuk pertemuan III siklus I, Materi yang disampaikan adalah Debit Fluida yang tersedia pada RPP_03 Siklus I yang tersedia pada Lampiran $\overline{0} 5$. Kegiatan ini dilakukan selama 2 jam pelajaran (JP) yaitu 90 menit, dengan pembagian waktu yaitu 30 menit teori dan 60 menit mengerjakan LKS.

\section{Pertemuan IV}

Untuk pertemuan IV siklus I, Materi yang disampaikan adalah Penerapan Hukum Bernaulli pada RPP 04 Siklus I yang tersedia pada Lampiran $\overline{0} 6$. Kegiatan ini dilakukan selama 2 jam pelajaran (JP) yaitu 90 menit, dengan pembagian waktu yaitu 30 menit teori dan 60 menit mengerjakan LKS.

\section{Pertemuan V}

Untuk pertemuan V siklus I, mengadakan pemberian tes akhir siklus I yang tersedia pada Lampiran 7.1 dengan jumlah soal pilihan ganda sebanyak 20 soal. Untuk materi yang diujikan adalah fluida kepada seluruh siswa kelas XI TKB 2 SMK Negeri 3 Singaraja yang dilakukan selama 2 jam pelajaran (JP) yaitu 90 menit.

\section{Tahap Observasi/Evaluasi Siklus I}

Ketika mengobservasi siswa, peneliti bersama guru melaksanakan tahap pengevaluasian. Hal-hal yang dapat diobservasi adalah sebagai berikut :

1) Mengobservasi proses pembelajaran yang dilakukan di kelas ketika siswa 
fokus pada suatu permasalahan, hal ini dapat menentukan tujuan dari permasalahan yang ada dalam diri siswa, jadi secara sistematis dalam menyusun dan melaksanakan langkah-langkah yang sudah direncanakan, peneliti dapat menemukan solusi dari permasalahan tersebut dan yang terakhir siswa dapat mengevaluasi solusi yang didapatkan.

2) Mengevaluasi hasil belajar siswa, dengan menggunakan LKS Individu RPP 01 sampai RPP 04 yang tersedia pada Lampiran 3.1, Lampiran 4.1, Lampiran 5.1 dan Lampiran 6.1 yaitu pada akhir pembelajaran, dan Tes Akhir Siklus diberikan pada akhir siklus I.

3) Mencatat fenomena yang diamati dan kendala-kendala yang ditemukan selama pelaksanaan tindakan.

\section{Refleksi}

Kegiatan refleksi dilaksanakan pada setiap akhir pembelajaran dan akhir siklus. Pada akhir pembelajaran yaitu diberikan setiap mengakhiri materi pada masing-masing pertemuan dan pada akhir siklus diberikan setelah menyelesaikan tes akhir. Sebagai acuan refleksi pada setiap akhir pembelajaran adalah kendala-kendala yang ditemui siswa dalam pembelajaran fisika melalui model pembelajaran Contextual Teaching and Learning. Refleksi yang dilakukan bertujuan untuk melihat kekurangan dan kelebihan setiap tindakan yang diberikan pada siklus I. Hasil-hasil refleksi tersebut selanjutnya digunakan sebagai bahan pertimbangan atau penyempurnaan dalam pelaksanaan tahapan-tahapan pada siklus II.

\section{Tahap Perencanaan Tindakan \\ Siklus II}

Perencanaan pada siklus II ini di dasarkan pada refleksi siklus I. Hal-hal yang dilakukan dalam perencanaan siklus II ini adalah:

1) Peneliti mensosialisasikan model pembelajaran kontekstual kepada guru mata pelajaran fisika untuk dilakukan dalam proses pembelajaran.

2) Menjabarkan materi pembelajaran menjadi sub-sub materi sesuai dengan pedoman kurikulum tingkat satuan pendidikan (KTSP).

3) Merumuskan indikator pembelajaran, sebagai pembatas tentang apa yang bisa diharapkan dan dipahami oleh siswa setelah mengikuti pembelajaran yang berdasarkan pada standar kompetensi mata pelajaran.

4) Menyusun rencana pelaksnaan pembelajaran (RPP) untuk siklus II pada pokok bahasan Suhu dan Kalor.

5) Menyiapkan instrumen penelitian untuk siklus II seperti Lembar Kerja Siswa (LKS) Individu RPP 08 sampai RPP 10 yang tersedia pada Lampiran 8.1, Lampiran 9.1, Lampiran 10.1 dan LKS Praktikum yang tersedia pada Lampiran 8.2 dan Lampiran 9.2 dengan terus berkonsultasi pada dosen pembimbing dan guru pamong yang nantinya digunakan sebagai tugas kelompok ataupun individu, tes akhir siklus, lembar observasi dan angket tanggapan siswa.

6) Membentuk kelompok siswa yang beranggotakan 4-5 orang. Pada masing-masing kelompok ditentukan ada ketua kelompok.

7) Menyiapkan kunci jawaban semua tes yang digunakan dalam penilaian serta dalam rangka memberikan balikan terstruktur.

\section{Tahap Pelaksanaan Tindakan Siklus II}

Proses pelaksanaan tindakan II ini melibatkan peran aktif guru dalam penyediaan waktu dan kesempatan kepada peneliti dalam menerapkan model pembelajaran kontekstual di dalam kelas. Tindakan yang dilakukan pada tahap siklus II ini dilaksanakan sebanyak 5 kali pertemuan.

\section{Pertemuan I}

Untuk pertemuan I siklus II, materi yang disampaikan adalah suhu dan thermometer pada RPP_01 Siklus II yang tersedia pada Lampiran 08. Kegiatan ini dilakukan selama 2 jam pelajaran (JP) yaitu 90 menit, dengan pembagian waktu 60 menit untuk teori dan 30 menit untuk praktikum.

\section{Pertemuan II}

Untuk pertemuan II siklus II, materi yang disampaikan adalah pengaruh kalor terhadap suatu zat pada RPP 02 Siklus II yang tersedia pada Lampiran 09 . Kegiatan ini dilakukan selama 2 jam pelajaran (JP) yaitu 90 menit, dengan pembagian waktu 60 menit untuk teori dan 30 menit untuk praktikum. 


\section{Pertemuan III}

Untuk pertemuan III siklus II, Materi yang disampaikan adalah Pemuaian zat dan penerapan konsep suhu kalor pada RPP 03 Siklus II yang tersedia pada Lampiran 10. Kegiatan ini dilakukan selama 2 jam pelajaran (JP) yaitu 90 menit, dengan pembagian waktu 60 menit untuk mengerjakam LKS dan 30 menit untuk teori.

\section{Pertemuan IV}

Untuk pertemuan IV siklus II, kegiatan yang dilakukan adalah mengadakan tes akhir siklus yang tersedia pada Lampiran 11.1 sebanyak 20 butir. Untuk materi yang diujikan adalah suhu dan kalor kepada seluruh siswa kelas XI TKB 2 SMK Negeri 3 Singaraja yang dilakukan selama 2 jam pelajaran (JP) yaitu 90 menit.

\section{Pertemuan V}

Pada pertemuan V siklus II siswa mengisi angket tanggapan siswa yang terdiri dari 10 pernyataan selama 1 jam pelajaran terhadap penerapan model contextual teaching and learning yang terdiri dari 10 pernyataan

Penelitian tindakan kelas ini terdiri dari dua siklus. Dalam setiap siklus dibagi menjadi 4 tahap kegiatan yaitu, (1) perencanaan, (2) tindakan, (3) observasi/evaluasi, dan (4) refleksi. Prosedur penelitian dilaksanakan, sebelum peneliti melakukan refleksi awal yang bertujuan untuk menjelaskan permasalahan serta kendala-kendala yang dialami siswa maupun guru. Instrumen penelitian data kinerja ilmiah siswa mengacu pada lembar observasi kinerja ilmiah, untuk hasil belajar mengacu pada tes akhir hasil belajar pada setiap akhir siklus dan tanggapan siswa mengacu pada angket tanggapan siswa.

\section{HASIL DAN PEMBAHASAN \\ A. HASIL PENELITIAN SIKLUS I}

Kegiatan pembelajaran siklus I dalam materi fluida dilaksanakan dalam lima kali pertemuan, dalam pertemuan tersebut 4 kali digunakan untuk melaksanakan kegiatan pembelajaran yang dilakukan dan, satu kali pertemuan untuk melaksanakan tes akhir siklus pertama. Sadangkan kegiatan pembelajaran siklus II dalam materi suhu-kalor dilaksanakan dalam lima kali pertemuan, dalam pertemuan tersebut 3 kali digunakan untuk melaksanakan kegiatan pembelajaran yang dilakukan, satu kali pertemuan untuk melaksanakan tes akhir siklus kedua dan satu kali pertemuan untuk melaksanakan pengisian angket tanggapan siswa.

Materi pembelajaran yang diberikan pada siklus I adalah fluida, dan pada siklus II adalah suhu-kalor. Pada siklus I skor rata-rata yang diperoleh siswa untuk kinerja ilmiah adalah sebesar 77,37 dengan kategori cukup tinggi yaitu berada dalam rentangan skor $62,5-79,5$. Sebanyak 10 anak mencapai kategori cukup tinggi, dan sebanyak 9 anak mencapai kategori tinggi. Sedangkan untuk skor rata-rata hasil belajar siswa adalah sebesar 73,0 dengan standar deviasinya 3,1. Pada siklus I, sebanyak 12 anak yang tuntas, dan 7 anak yang belum tuntas sehingga diberikan perbaikan pada siklus II. Untuk siklus II skor rata-rata kinerja ilmiah mengalami peningkatan dari siklus I yaitu sebesar 87,9 dengan kategori sangat tinggi yaitu berada dalam skor di atas 87,5. Sebanyak 10 anak mencapai kategori sangat tinggi, dan sebanyak 9 anak mencapai kategori tinggi. Sedangkan untuk skor rata-rata hasil belajar siswa untuk siklus II adalah sebesar 77,5 dengan standar deviasinya 1,4 . Jika dibandingkan dengan siklus I, pada siklus II nilai hasil belajar dan kinerja ilmiah siswa mengalami peningkatan, walaupun dalam siklus II masih ada beberapa siswa yang belum mencapai standar ketuntasan yang ditetapkan. Berikut ini akan dijelaskan deskripsi proses pembelajaran dari hasil penelitian siklus I dan siklus II.

Secara lebih jelas, deskripsi proses pembelajaran yang dilaksanakan, dapat dipaparkan sebagai berikut:

\section{1) Pertemuan Pertama}

Materi untuk pertemuan pertama adalah Tekanan Hidrostatis dan Hukum Archimedes dengan alokasi waktu yang diberikan adalah 90 menit atau 2 jam pelajaran.

Kegiatan pendahuluan terdiri dari memusatkan perhatian siswa sebelum memulai pembelajaran yang akan dilakukan di dalam kelas, dilanjutkan dengan memberikan batasan (strukturing), menyampaikan tujuan dalam kegiatan pembelajaran. Menggali pengetahuan awal siswa dengan mengajukan sebuah pertanyaan yaitu Sebutkan contoh penerapan tekanan hidrostatis dalam kehidupan sehari-hari! 
Siswa memberikan pendapat berbagai macam, ada yang mendekati benar dan ada juga yang kurang tepat menjawabnya. Sehingga dari pendapat siswa tersebut dapat disimpulkan menjadi satu jawaban.

Kegiatan inti terdiri dari kegiatan invitasi, eksplorasi, penjelasan solusi dan pengambilan tindakan. Tahapan atau sintax pembelajaran yang dilakukan adalah siswa didorong untuk mengungkapkan pengetahuan awal yang mereka miliki seperti kasus diatas. Agar siswa tersebut bisa atau mulai berpikir dan mengungkapkan pendapat yang mereka miliki, dengan begitu bisa disimpulkan pendapat para siswa tentang pertanyaan tersebut. Siswa menjawab pertanyaan yang sudah disampaikan oleh guru, kegiatan ini yang yang lebih ditekankan adalah siswa. Guru menyimpulkan jawaban siswa yaitu pada pembuatan sebuah bendungan, pada proses pembuatan bendungan ini dibuat lebih tebal untuk mengetahui tekanan hidrostatis tersebut. Masih dalam tahapan invitasi kegiatan bertanya juga dilakukan sama seperti halnya diatas. Siswa diberikan kesempatan untuk menjawab sebuah pertanyaan melalui tahapan eksplorasi mengenai topik tekanan hidrostatis dan hukum archimedes dengan memusatkan perhatian siswa dan memberikan pertanyaan secara mandiri untuk menggali pengetahuan siswa dan menuntun siswa menuju pada topik yang akan dibahas. Pertanyaan tersebut tercantum dalam (LKS Individu RPP_01 Siklus I) tentang materi hukum tekanā̄ hidrostatis, dan hukum archimedes, dan kegiatan ini termasuk kegiatan Inquiry (menemukan). Kegiatan yang ditekankan dalam hal ini adalah siswa. Setelah kegiatan itu dilaksanakan, selanjutnya siswa diminta untuk mengajukan hipotesis awal atau jawaban sementara dari permasalahan yang ada di atas melalui menyampaikan hasil jawaban LKS individu RPP 01 Siklus I. Kegiatan yang ditekankan dalam hal ini ada siswa. Hasil rata-rata yang diperoleh siswa adalah sebesar 70,8 ini membuktikan bahwa siswa belum mencapai KKM yang ditetapkan sebesar 75 dan keantusiasan siwa akan pada pertemuan pertama masih belum dikatakan optimal sehingga untuk pertemuan kedua siswa bisa lebih diarahkan keseriusannya agar bisa mencapai nilai yang maksimal. Kegiatan selanjutnya masih dalam tahapan eksplorasi adalah siswa mengerjakan LKS secara kelompok (LKS Praktikum RPP_01 Siklus I) dan perwakilan kelompok melaporkan hasil praktikumnya. Kegiatan ini lebih ditekankan kepada siswa dan kegiatan guru hanyalah menanggapi pendapat dari masing-masing kelompok. Kegiatan ini termasuk kegiatan masyarakat belajar (Learning Community) dan apabila ada hal-hal yang kurang jelas untuk dimengerti oleh masing-masing kelompok, siswa dalam kelompok itu bisa menanyakan pada guru. Kegiatan ini termasuk bagian dari kegiatan bertanya (Questioning). Guru dalam kegiatan ini adalah hanyalah sebagai fasilitator apabila ada salah satu siswa yang mengalami kendala dalam mengerjakan LKS tersebut, ini termasuk dalam pemodelan. Kegiatan ini yang lebih ditekankan adalah kegiatan guru, sedangkan siswa dituntut lebih berperan aktif dalam hal menemukan (Inquiry). Pada tahapan penjelasan dan solusi, Siswa memberikan penjelasan-penjelasan serta solusi yang didasarkan pada hasil observasinya ditambah dengan penguatan yang diberikan oleh guru. Siswa tersebut dapat menyampaikan gagasan, membuat model, membuat rangkuman (Kegiatan Inquiry), dan kegiatan guru hanyalah membimbing siswa (Pemodelan) dan keseluruhan dari kegiatan ini adalah kegiatan refleksi. Tahapan yang terakhir adalah pengambilan tindakan yang menjadi kegiatan pembelajarannya adalah penilaian sebenarnya atau authentic assesment, pada kegiatan pembelajaran ini siswa dapat membuat keputusan, menggunakan pengetahuan dan ketrampilan, berbagai informasi dan gagasan, mengajukan pertanyaan lanjutan dan saran baik secara individu maupun kelompok yang berhubungan dengan pemecahan masalah khususnya pada materi tekanan hidrostatis dan hukum archimedes.

Kegiatan penutup terdiri dari siswa membuat rangkuman tentang materi yang sudah dijelaskan dengan bimbingan guru dan sebagai tindak lanjut dan diberikan Tugas Rumah RPP_01 Siklus I dan hasil rata-ratanya adalah sebesar 69,9 dan dikatakan belum mencapai standar ketuntasan yang ditetapkan, sehingga pada pertemuan selanjutnya siswa bisa menyiapkan dan memantapkan materi lebih matang, lalu pelajaran diakhiri dengan menyampaikan salam penutup. Hasil refleksi pada pertemuan pertama ini siswa diberikan evalu- 
asi diri untuk bisa melihat kembali tentang pembelajaran yang dilakukan pada pertemuan pertama yang bertujuan agar pertemuan kedua nanti siswa diharapkan lebih serius untuk mengikuti pembelajaran yang dilakukan.

\section{2) Pertemuan Kedua}

Materi untuk pertemua kedua adalah Hukum Pascall dengan alokasi waktu 90 menit atau 2 jam pelajaran. Kegiatan pendahuluan terdiri dari memusatkan perhatian siswa sebelum memulai pembelajaran yang akan dilakukan di dalam kelas, dilanjutkan dengan memberikan batasan (strukturing), menyampaikan tujuan dalam kegiatan pembelajaran. Menggali pengetahuan awal siswa dengan mengajukan sebuah pertanyaan yaitu Apakah anakanak pernah melihat pompa sepeda dirumah kalian? Bagaiamana cara kerja pompa sepeda yang pernah kalian lihat tersebut? Siswa memberikan pendapat berbagai macam, ada yang mendekati benar dan ada juga yang kurang tepat menjawabnya. Sehingga dari pendapat siswa tersebut dapat disimpulkan menjadi satu jawaban.

Kegiatan inti terdiri dari kegiatan invitasi, eksplorasi, penjelasan solusi dan pengambilan tindakan. Tahapan atau sintax pembelajaran yang dilakukan adalah siswa didorong untuk mengungkapkan pengetahuan awal yang mereka miliki seperti kasus diatas agar siswa tersebut bisa berpikir dan mengungkapkan pendapat yang mereka miliki sehingga bisa disimpulkan dari pendapat siswa tentang pertanyaan tersebut. Siswa menjawab pertanyaan yang disampaikan oleh guru, kegiatan yang yang lebih ditekankan adalah siswa. Guru menyimpulkan jawaban siswa yaitu pompa hidrolik sering dijumpai oleh anak-anak dimasyarakat saat ini dan cara kerja pompa hidrolik gaya F1 diberikan melalui tuas dongkrak untuk menekan penghisap kecil A1, tekanan ini akan diteruskan oleh minyak ke segala arah. Kegiatan diatas masih dalam tahapan invitasi adalah bertanya (questioning), kegiatan bertanya juga dilakukan sama seperti halnya di atas. Pada kegiatan pembelajaran siswa diberikan kesempatan untuk menjawab sebuah pertanyaan melalui tahapan eksplorasi mengenai topik hukum pascall dengan memusatkan perhatian siswa dan memberikan pertanyaan secara mandiri untuk menggali pengetahuan siswa dan menuntun siswa menuju pada topik yang akan dibahas. Pertanyaan tersebut tercantum dalam (LKS Individu RPP 02 Siklus I) tentang materi hukum pascall, dan kegiatan ini termasuk kegiatan Inquiry (Menemukan). Kegiatan yang ditekankan dalam hal ini adalah kegiatan siswa. Hasil rata-rata yang diperoleh siswa adalah sebesar 71,3. Hasil yang diperoleh pada pertemuan kedua ada sedikit peningkatan dari pertemuan pertama. Sehingga untuk pertemuan ketiga siswa bisa lebih diarahkan keseriusannya agar bisa mencapai nilai yang maksimal. Kegiatan selanjutnya masih dalam tahapan eksplorasi adalah siswa mengerjakan LKS secara kelompok (LKS Praktikum RPP_02 Siklus I) dan perwakilan kelompok melaporkan hasil praktikumnya. Kegiatan ini lebih ditekankan kepada siswa dan kegiatan guru hanyalah menanggapi pendapat dari masing-masing kelompok. Kegiatan ini termasuk kegiatan masyarakat belajar (Learning Community) dan apabila ada hal-hal yang kurang jelas untuk dimengerti oleh masing-masing kelompok, siswa dalam kelompok itu bisa menanyakan pada guru. Kegiatan ini termasuk bagian dari kegiatan bertanya (Questioning). Guru dalam kegiatan ini adalah hanyalah sebagai fasilitator apabila ada salah satu siswa yang mengalami kendala dalam mengerjakan LKS tersebut, ini termasuk dalam pemodelan. Kegiatan ini yang lebih ditekankan adalah kegiatan guru, sedangkan siswa dituntut lebih berperan aktif dalam hal menemukan (Inquiry). Pada tahapan penjelasan dan solusi, Siswa memberikan penjelasan-penjelasan serta solusi yang didasarkan pada hasil observasinya ditambah dengan penguatan yang diberikan oleh guru. Siswa tersebut dapat menyampaikan gagasan, membuat model, membuat rangkuman (Kegiatan Inquiry), dan kegiatan guru hanyalah membimbing siswa (Pemodelan) dan keseluruhan dari kegiatan ini adalah kegiatan refleksi. Tahapan yang terakhir adalah pengambilan tindakan yang menjadi kegiatan pembelajarannya adalah penilaian sebenarnya atau authentic assesment, pada kegiatan pembelajaran ini siswa dapat membuat keputusan, menggunakan pengetahuan dan ketrampilan, berbagai informasi dan gagasan, mengajukan pertanyaan lanjutan dan saran baik secara individu maupun kelompok yang 
berhubungan dengan pemecahan masalah khususnya pada materi hukum pascall.

Kegiatan penutup siswa membuat rangkuman tentang materi yang sudah dijelaskan dengan bimbingan guru dan sebagai tindak lanjut dan diberikan Tugas Rumah RPP 02 Siklus I dan hasil rata-ratanya adalā̄ sebesar 71,7. Hasil ini juga lebih kecil dari pertemuan pertama dan belum dikatakan mencapai standar ketuntasan yang ditetapkan, karena pada materi ini siswa masih belum banyak yang memahami sehingga akan berpengaruh pada nilai hasil belajar siswa. Agar bisa memperoleh nilai yang maksimal, siswa pada pertemuan ketiga diharapkan bisa lebih serius untuk mengikuti pembelajaran fisika, Hasil refleksi pada pertemuan kedua ini siswa diberikan evaluasi diri untuk bisa melihat kembali tentang pembelajaran yang dilakukan agar pertemuan ketiga nanti siswa diharapkan lebih serius untuk mengikuti pembelajaran yang dilakukan. lalu pelajaran berakhir diakhiri dengan menyampaikan salam penutup.

\section{3) Pertemuan Ketiga}

Materi untuk pertemuan ketiga adalah Debit Fluida dengan alokasi waktu yang diberikan adalah 90 menit atau 2 jam pelajaran. Kegiatan pendahuluan terdiri dari memusatkan perhatian siswa sebelum memulai pembelajaran, memberikan batasan (strukturing), menyampaikan tujuan dalam kegiatan pembelajaran, menggali pengetahuan awal siswa dengan mengajukan pertanyaan yaitu Ketika kita mengendarai sepeda motor, tiba-tiba ada sebuah mobil mendahului dengan posisi sangat berdekatan, dalam hal ini pastilah kita merasakan suatu tarikan ke arah mobil tersebut. Mengapa hal ini bisa terjadi? Mengapa ketika orang berperahu di sebuah sungai akan merasakan arus bertambah keras ketika sungai menyempit? Siswa memberikan pendapat berbagai macam, ada yang mendekati benar dan ada juga yang kurang tepat menjawabnya. Sehingga dari pendapat siswa tersebut disimpulkan menjadi satu jawaban yang benar dan dimengerti oleh siswa.

Kegiatan inti terdiri dari kegiatan invitasi, eksplorasi, penjelasan solusi dan pengambilan tindakan. Tahapan atau sintax pembelajaran yang dilakukan yaitu siswa didorong untuk mengemukakan pengetahuan awal atau konsep awal yang mereka miliki seperti kasus contoh hukum pascall dalam kehidupan sehari-hari agar nanti siswa tersebut bisa berpikir dan mengungkapkan pendapat yang mereka miliki sehingga bisa disimpulkan dari pendapat siswa tentang pertanyaan tersebut. Siswa menjawab pertanyaan yang sudah disampaikan oleh guru, kegiatan ini yang yang lebih ditekankan adalah siswa. Guru menyimpulkan jawaban siswa yaitu karena ruang antara sepeda motor dengan mobil cukup sempit sehingga kecepatan udara menjadi lebih cepat dibanding pada tempat lain. Dan ketika orang berperahu di sebuah sungai akan merasakan arus bertambah keras ketika sungai menyempit karena kecepatan fluida berkurang ketika melewati pipa lebar dan bertambah ketika melewati pipa sempit. Masih dalam tahapan invitasi adalah bertanya (questioning), kegiatan bertanya juga dilakukan sama seperti halnya diatas. Siswa diberikan kesempatan untuk menjawab sebuah pertanyaan melalui tahapan eksplorasi dengan memusatkan perhatian siswa dan memberikan pertanyaan secara mandiri untuk menggali pengetahuan siswa dan menuntun siswa menuju pada topik yang akan dibahas. Pertanyaan tersebut tercantum dalam (LKS Individu RPP_03 Siklus I) tentang materi debit fluida, dan kegiatan ini termasuk kegiatan Inquiry (Menemukan). Kegiatan yang ditekankan dalam hal ini adalah kegiatan siswa. Setelah kegiatan itu dilaksanakan, selanjutnya meminta siswa untuk mengajukan hipotesis awal atau jawaban sementara dari permasalahan yang ada di atas melalui menyampaikan hasil jawaban LKS individu RPP 03 Siklus I. Hasil rata-rata yang diperole⿳亠 siswa adalah sebesar 72,8. Hasil ini sudah ada kenaikan dari pertemuan kedua, meskipun belum mencapai nilai maksimal tetapi antusias siswa lebih baik dari sebelumnya. Tahapan penjelasan dan solusi, siswa memberikan penjelasan-penjelasan serta solusi yang didasarkan pada hasil observasinya ditambah dengan penguatan yang diberikan oleh guru. Siswa tersebut menyampaikan gagasan, membuat model, membuat rangkuman (Kegiatan Inquiry), dan kegiatan guru hanyalah membimbing siswa (Pemodelan) dan keseluruhan dari kegiatan ini adalah kegiatan refleksi. Tahapan yang terakhir adalah pengambilan tindakan yang 
menjadi kegiatan pembelajarannya adalah penilaian sebenarnya atau authentic assesment

Kegiatan penutup siswa membuat rangkuman tentang materi yang sudah dijelaskan dengan bimbingan guru dan sebagai tindak lanjut dan diberikan Tugas Rumah RPP 03 Siklus I dan hasil rata-ratanya adalah sebesar 74,2. Hasil dari pertemuan ketiga mengalami peningkatan dari pertemuan kedua meskipun belum maksimal tetapi sudah ada peningkatan dari sebelumnya, karena pada materi ini siswa sudah mulai mengerti sehingga ada pengaruhnya pada nilai siswa dan pada pertemuan keempat diharapkan bisa lebih serius untuk mengikuti pembelajaran fisika, Hasil refleksi pada pertemuan ketiga ini siswa diberikan evaluasi diri untuk bisa melihat kembali tentang pembelajaran yang dilakukan agar pada pertemuan keempat nanti siswa diharapkan lebih serius untuk mengikuti pembelajaran yang dilakukan. Lalu pelajaran berakhir diakhiri dengan menyampaikan salam penutup.

\section{4) Pertemuan Keempat}

Materi yang diberikan adalah Penerapan Hukum Bernaulli dengan alokasi waktu yang diberikan adalah 90 menit atau 2 jam pelajaran. Kegiatan pendahuluan terdiri dari memusatkan perhatian siswa sebelum memulai pembelajaran, memberikan batasan (strukturing), menyampaikan tujuan dalam kegiatan pembelajaran, menggali pengetahuan awal siswa dengan mengajukan sebuah pertanyaan yang menyangkut tentang debit fluida yaitu Pernahkah melihat tangki air yang dilubangi? Apakah yang menyebabkan terjadinya gaya angkat pesawat? Jawaban yang diberikan oleh siswa berbagai macam, ada yang mendekati benar dan ada juga yang kurang tepat menjawabnya. Sehingga dari pendapat siswa tersebut dapat disimpulkan menjadi satu jawaban.

Kegiatan inti terdiri dari kegiatan invitasi, eksplorasi, penjelasan solusi dan pengambilan tindakan. Tahapan atau sintax pembelajaran yang dilakukan adalah siswa didorong untuk mengemukakan pengetahuan awal atau konsep awal yang mereka miliki. Kegiatan ini diharapkan nantinya siswa bisa berpikir dan mengungkapkan pendapat yang mereka miliki agar bisa dijadikan suatu kesimpulan. Siswa menjawab pertanyaan yang sudah disampaikan oleh guru, yang lebih ditekankan adalah siswa. Guru menyimpulkan jawaban siswa yaitu air tangki yang dilubangi semua pernah melihatnya dan yang menyebabkan terjadinya gaya angkat pesawat adalah karena adanya aliran udara yang melalui aliran udara yang melalui sayapnya. Kegiatan diatas masih dalam tahapan invitasi adalah bertanya (questioning), kegiatan bertanya juga dilakukan sama seperti halnya diatas. Pada kegiatan pembelajaran ini siswa diberikan kesempatan untuk menjawab sebuah pertanyaan melalui tahapan eksplorasi mengenai topik penerapan hukum bernaulli dengan memusatkan perhatian siswa dan memberikan pertanyaan secara mandiri untuk menggali pengetahuan siswa dan menuntun siswa menuju pada topik yang akan dibahas. Pertanyaan tersebut tercantum dalam (LKS Individu RPP_04 Siklus I) dan kegiatan ini termasuk kegiatan Inquiry (Menemukan). Kegiatan yang ditekankan dalam hal ini adalah kegiatan siswa., selanjutnya meminta siswa untuk mengajukan hipotesis awal atau jawaban sementara dari permasalahan yang ada di atas melalui menyampaikan hasil jawaban LKS individu RPP_04 Siklus I. Kegiatan yang ditekankan dālam hal ini ada siswa. Hasil rata-rata yang diperoleh adalah sebesar 77,2 dan hasil sudah mencapai standar ketuntasan yang ditetapkan adalah 75 . Pada tahapan penjelasan dan solusi, Siswa memberikan penjelasan-penjelasan serta solusi yang didasarkan pada hasil observasinya ditambah dengan penguatan yang diberikan oleh guru. Siswa tersebut dapat menyampaikan gagasan, membuat model, membuat rangkuman (Kegiatan Inquiry), dan kegiatan guru hanyalah membimbing siswa (Pemodelan) dan keseluruhan dari kegiatan ini adalah kegiatan refleksi. Tahapan yang terakhir adalah pengambilan tindakan yang menjadi kegiatan pembelajarannya adalah penilaian sebenarnya atau authentic assesment, pada kegiatan pembelajaran ini siswa dapat membuat keputusan, menggunakan pengetahuan dan ketrampilan, berbagai informasi dan gagasan, mengajukan pertanyaan lanjutan dan saran baik secara individu maupun kelompok yang berhubungan dengan pemecahan masalah khususnya pada materi penerapan hukum bernaulli.

Kegiatan penutup terdiri dari siswa 
membuat rangkuman tentang materi yang sudah dijelaskan dengan bimbingan guru dan sebagai tindak lanjut dan diberikan Tugas Rumah RPP 04 Siklus I dan hasil rata-ratanya adalah sebesar 78,8 Hasil dari pertemuan keempat mengalami peningkatan dari pertemuan ketiga karena pada materi ini siswa sudah mulai mengerti sehingga ada pengaruhnya pada nilai siswa Hasil refleksi pada pertemuan keempat ini siswa diberikan evaluasi diri untuk bisa menghadapi tes akhir siklus pada pertemuan selanjutnya. Lalu pelajaran berakhir diakhiri dengan menyampaikan salam penutup.

\section{5) Pertemuan Kelima}

Pertemuan kelima diadakan tes akhir siklus dalam alokasi waktu yaitu 90 menit yang mencakup materi fluida, tujuannya adalah untuk mengetahui hasil belajar yang dilakukan oleh siswa di kelas XI TKB 2. Pertemuan diawali dengan mengucapkan salam pembuka dan mengecek daftar hadir atau pengabsenan siswa. Sebelum waktu memulai pengerjaan soal dimulai, peneliti menekankan tata cara menjawab tes. Seluruh siswa sebanyak 19 orang diberi kesempatan untuk memasukkan semua buku fisika dan hanya ada alat tulis di atas meja. Seluruh siswa dibagikan soal dan diminta mengisi identitas secara lengkap. Tes dibagikan dan siswa mulai mengerjakan tes tersebut. Pembahasan yang akan dijawab oleh siswa diletakan atau dijawab di bawah soal.

Selama siswa mengerjakan tes, peneliti yang dibantu oleh seorang rekan dan guru fisika berkeliling mengawasi keadaan siswa untuk menghindari adanya siswa yang menyontek dan bekerjasama, sehingga siswa dapat benar-benar mengerjakan tes tersebut dengan tertib. Jika ada siswa yang menggangu siswa lainnya selama pengerjaan tes, maka peneliti berusaha mendekati dan memberikan teguran. Ketika waktu pengerjaan tes sudah berakhir, siswa diminta untuk mengumpulkan lembar jawaban beserta tes yang diberikan. Sebagai penutup pertemuan,. Pertemuan ditutup dengan mengucapkan salam penutup.

Data deskripsi hasil penelitian ini meliputi deskripsi yaitu hasil belajar, kinerja ilmiah, dan tanggapan siswa terhadap penerapan model contextual teaching and learning dalam pembelajaran fisika pada kelas XI TKB 2 di SMK Negeri 3 Singaraja. Pengumpulan data untuk aspek kinerja ilmiah dilakukan dengan metode observasi yang mengacu pada lembar observasi kinerja ilmiah. Secara lebih ringkas nilai rata-rata masing-masing kategori ditunjukkan pada Tabel 1 berikut:

Tabel 1 Nilai Rata-Rata Kinerja Ilmiah Siswa Siklus I

\begin{tabular}{|l|l|l|l|}
\hline No & Siswa & Rata-Rata & \multicolumn{1}{|c|}{ Kategori } \\
\hline 1 & 1 & 80.00 & Tinggi \\
\hline 2 & 2 & 80.00 & Tinggi \\
\hline 3 & 3 & 72.50 & Cukup Tinggi \\
\hline 4 & 4 & 80.00 & Tinggi \\
\hline 5 & 5 & 78.75 & Cukup Tinggi \\
\hline 6 & 6 & 80.00 & Tinggi \\
\hline 7 & 7 & 81.25 & Tinggi \\
\hline 8 & 8 & 78.75 & Cukup Tinggi \\
\hline 9 & 9 & 81.25 & Tinggi \\
\hline 10 & 10 & 73.75 & Cukup Tinggi \\
\hline 11 & 11 & 73.75 & Cukup Tinggi \\
\hline 12 & 12 & 71.25 & Cukup Tinggi \\
\hline 13 & 13 & 78.75 & Cukup Tinggi \\
\hline 14 & 14 & 80.00 & Cukup Tinggi \\
\hline 15 & 15 & 80.00 & Tinggi \\
\hline 16 & 16 & 80.00 & Tinggi \\
\hline 17 & 17 & 80.00 & Tinggi \\
\hline 18 & 18 & 68.75 & Cukup Tinggi \\
\hline 19 & 19 & 71.25 & Cukup Tinggi \\
\hline Rata-Rata & 77,37 & \\
\hline
\end{tabular}

Berdasarkan tabel 4.1, nilai rata-rata kinerja ilmiah siswa pada siklus I sebesar 77,37. Bila ditinjau skor masing-masing anak, terlihat bahwa sebanyak 9 anak termasuk dalam kategori tinggi, dan 10 anak termasuk cukup tinggi. Jika dikonversi ke skala SDI dan MI. maka dapat digambarkan seperti tabel 2: Berdasarkan tabel 4.1, nilai rata-rata kinerja ilmiah siswa pada siklus I sebesar 77,37. Bila ditinjau skor masing-masing anak, terlihat bahwa sebanyak 9 anak termasuk dalam kategori tinggi, dan 10 anak termasuk cukup tinggi. Jika dikonversi ke skala SDI dan MI. maka dapat digambarkan seperti tabel 2: 
Tabel 2 Kriteria Kinerja Ilmiah Siswa Hasil Observasi

\begin{tabular}{|l|l|l|r|r|}
\hline No & Kriteria & Kategori & $\mathbf{( f )}$ & $\mathbf{( \% )}$ \\
\hline 1 & $\bar{X}_{\geq 87,5}$ & $\begin{array}{l}\text { Sangat } \\
\text { tinggi }\end{array}$ & 0 & 0 \\
\hline 2 & $\begin{array}{l}80,0 \leq \bar{X} \\
<87,5\end{array}$ & Tinggi & 9 & 47,37 \\
\hline 3 & $\begin{array}{l}62,5 \leq \bar{X} \\
<79,5\end{array}$ & $\begin{array}{l}\text { Cukup } \\
\text { tinggi }\end{array}$ & 10 & 57,63 \\
\hline 4 & $\begin{array}{l}37,5 \leq \bar{X} \\
<62,5\end{array}$ & $\begin{array}{l}\text { Kurang } \\
\text { tinggi }\end{array}$ & 0 & 0 \\
\hline 5 & $\begin{array}{l}\bar{X}_{<}<37,5 \\
\text { kurang } \\
\text { tinggi }\end{array}$ & 0 & 0 \\
\hline
\end{tabular}

Berdasarkan tabel 2 diatas, kategori yang diperoleh siswa untuk kinerja ilmiah adalah cukup tinggi berada dalam rentangan $62,5 \leq \ddot{X}<79,5$ sebanyak 10 anak, sedangkan siswa yang berkategori tinggi adalah sebanyak 9 anak, sehingga untuk nilai kinerja ilmiah pada siklus I belum bisa dikatakan optimal.

Untuk nilai akhir rata-rata hasil belajar ditunjukan pada tabel 3 yaitu sebagai berikut:

Tabel 3 Nilai Hasil Belajar Fisika Siswa Pada Siklus I

\begin{tabular}{|l|c|c|l|}
\hline No & Siswa & Rata-Rata & Kategori \\
\hline 1 & 1 & 75.3 & Tuntas \\
\hline 2 & 2 & 68.3 & Tidak Tuntas \\
\hline 3 & 3 & 75.4 & Tuntas \\
\hline 4 & 4 & 75.9 & Tuntas \\
\hline 5 & 5 & 77.9 & Tuntas \\
\hline 6 & 6 & 68.9 & Tidak Tuntas \\
\hline 7 & 7 & 75.0 & Tuntas \\
\hline 8 & 8 & 72.3 & Tidak Tuntas \\
\hline 9 & 9 & 67.9 & Tidak Tuntas \\
\hline 10 & 10 & 75.1 & Tuntas \\
\hline 11 & 11 & 74.9 & Tuntas \\
\hline 12 & 12 & 75.6 & Tuntas \\
\hline
\end{tabular}

\begin{tabular}{|l|l|l|l|}
\hline 13 & 13 & 67.8 & Tidak Tuntas \\
\hline 14 & 14 & 75.6 & Tuntas \\
\hline 15 & 15 & 75.4 & Tuntas \\
\hline 16 & 16 & 75.4 & Tuntas \\
\hline 17 & 17 & 69.6 & Tidak Tuntas \\
\hline 18 & 18 & 75.1 & Tuntas \\
\hline 19 & 19 & 69.3 & Tidak Tuntas \\
\hline \multicolumn{2}{|l}{ Rata-Rata } & $\mathbf{7 3 , 0}$ & \\
\hline
\end{tabular}

Berdasarkan tabel diatas, untuk nilai rata-rata hasil belajar siswa adalah nilai rata-rata hasil belajar siswa pada siklus I sebesar 73,0. Bila ditinjau nilai masing-masing anak, terlihat bahwa sebanyak 7 anak tidak tuntas, dan 12 anak tuntas. Untuk nilai rata-rata komponen hasil belajar ditunjukan pada tabel 4 adalah sebagai berikut:

\section{Tabel 8 Nilai Rata-Rata Komponen} Hasil Belajar Siswa Siklus II

\begin{tabular}{|l|l|l|l|c|}
\hline \multirow{2}{*}{ Deskripsi } & \multicolumn{3}{|c|}{$\begin{array}{c}\text { Penilaian Hasil } \\
\text { Belajar }\end{array}$} & \multirow{2}{*}{ Nilai Akhir } \\
\cline { 2 - 4 } & $\ddot{X}_{\text {LKS.In }}$ & $\ddot{X}_{\text {T.R }}$ & X $_{\text {T.A }}$ & \\
\hline $\begin{array}{l}\text { Nilai } \\
\text { Rata-rata }\end{array}$ & 76,7 & 79,1 & 76,8 & 77,5 \\
\hline $\begin{array}{l}\text { Standar } \\
\text { Deviasi }\end{array}$ & 1,3 & 2,2 & 2,4 & 1,4 \\
\hline $\begin{array}{l}\text { Nilai } \\
\text { Tertinggi } \\
\text { E75 }\end{array}$ & 18 & 18 & 19 & \\
\hline $\begin{array}{l}\text { Nilai } \\
\text { Terendah } \\
\text { E75 }\end{array}$ & 1 & 1 & 0 & \\
\hline
\end{tabular}

Berdasarkan tabel 8, untuk nilai rata-rata hasil belajar siswa ditentukan berdasarkan nilai LKS individu, tugas rumah dan tes akhir siklus. Secara klasikal nilai rata-rata LKS individu adalah 76,7 dengan standar deviasi 1,3 , nilai rata-rata tugas rumah 79,1 dengan standar deviasi 2,2 dan nilai rata-rata tes akhir hanya mencapai 76,8 dengan standar deviasi 2,4. Ini membuktikan bahwa siswa di kelas XI TKB 2 SMK Negeri 3 Singaraja sudah mencapai KKM yang ditetapkan sebesar 75 .

Hasil tanggapan siswa untuk masing-masing kategori disajikan pada Tabel 9 adalah sebagai berikut: 
Tabel 9 Nilai Rata-Rata Tanggapan Siswa

\begin{tabular}{|l|c|c|l|}
\hline No & Siswa & Rata-Rata & Kategori \\
\hline 1 & 1 & 42 & Positif \\
\hline 2 & 2 & 40 & Positif \\
\hline 3 & 3 & 39 & Positif \\
\hline 4 & 4 & 46 & Sangat Positif \\
\hline 6 & 5 & 40 & Positif \\
\hline 7 & 6 & 41 & Positif \\
\hline 8 & 8 & 39 & Positif \\
\hline 9 & 9 & 41 & Positif \\
\hline 10 & 10 & 30 & Positif \\
\hline 11 & 11 & 47 & Cukup Positif \\
\hline 12 & 12 & 40 & Sangat Positif \\
\hline 13 & 13 & 33 & Positif \\
\hline 14 & 14 & 43 & Positif Positif \\
\hline 15 & 15 & 41 & Positif \\
\hline 16 & 16 & 40 & Positif \\
\hline 17 & 17 & 41 & Positif \\
\hline 18 & 18 & 34 & Cukup Positif \\
\hline 19 & 19 & 32 & Cukup Positif \\
\hline Rata-Rata & $\mathbf{3 9 , 3}$ & \\
\hline
\end{tabular}

Berdasarkan tabel 9, skor rata-rata tanggapan siswa pada siklus II sebesar 39,3. Bila ditinjau nilai masing-masing anak, terlihat bahwa sebanyak 2 anak berkategori sangat positif, 13 anak berkategori positif, dan 4 anak berkategori cukup positif. Jika dikonversi ke skala SDI dan MI maka dapat digambarkan seperti tabel 10 sebagai berikut:

Tabel 10 Kriteria Tanggapan Siswa

\begin{tabular}{|l|l|l|l|l|}
\hline No & Kriteria & Kategori & (f) & $(\mathbf{\%})$ \\
\hline 1 & $\ddot{X} \geq 45,0$ & $\begin{array}{l}\text { Sangat } \\
\text { Positif }\end{array}$ & 2 & 10,5 \\
\hline 2 & $\begin{array}{l}35,0 \leq \\
\ddot{X}<45,0\end{array}$ & Positif & 13 & 68,4 \\
\hline 3 & $\begin{array}{l}25,0 \leq \\
\ddot{X}<35,0\end{array}$ & $\begin{array}{l}\text { Cukup } \\
\text { Positif }\end{array}$ & 4 & 21,1 \\
\hline 4 & $\begin{array}{l}15,0 \leq \\
\ddot{X}<25,0\end{array}$ & $\begin{array}{l}\text { Kurang } \\
\text { Positif }\end{array}$ & 0 & 0 \\
\hline
\end{tabular}

\begin{tabular}{|l|l|l|l|l|}
\hline 5 & $\ddot{X}<15,0$ & $\begin{array}{l}\text { Sangat } \\
\text { Kurang } \\
\text { Positif }\end{array}$ & 0 & 0 \\
\hline \multicolumn{2}{|c|}{ Total } & $\mathbf{1 9}$ & $\mathbf{1 0 0}$ \\
\hline
\end{tabular}

Berdasarkan tabel di atas menunjukkan bahwa tanggapan siswa berada pada kategori positif dengan skor rata-rata sebesar 39,3 sebanyak 13 orang dalam rentangan $35,0 \leq \ddot{X}<45,0$. Siswa menyarankan agar model pembelajaran CTL tetap digunakan di kelas XI TKB 2 SMK Negeri 3 Singaraja.

\section{PEMBAHASAN}

Berdasarkan hasil penelitian yang telah dilaksanakan selama dua siklus di kelas XI TKB 2 SMK Negeri 3 Singaraja pada semester ganjil tahun pelajaran 2013/2014 untuk pokok bahasan suhu dan kalor menunjukkan bahwa adanya peningkatan hasil belajar fisika, kinerja ilmiah, dan kualitas pembelajaran fisika melalui penerapan model pembelajaran contextual teaching and learning. Sebagai pendukung hal tersebut, berikut akan disampaikan perbandingan nilai kinerja ilmiah siswa saat siklus I dan siklus II disajikan pada tabel 11 sebagai berikut:

Tabel 11 Perbandingan Nilai Kinerja Ilmiah Siswa Saat Siklus I dan Siklus II

\begin{tabular}{|l|c|c|}
\multirow{2}{*}{ Deskripsi } & \multicolumn{2}{|c|}{ Kinerja Ilmiah } \\
\cline { 2 - 3 } & Siklus I & Siklus II \\
\hline Nilai Rata-Rata & 86,32 & 87,90 \\
\hline Standar Deviasi & 7,5 & 2,5 \\
\hline Nilai Tertinggi & 92,5 & 93,8 \\
\hline Nilai Terendah & 72,5 & 83,8 \\
\hline
\end{tabular}

Berdasarkan tabel di atas bahwa ada peningkatan nilai kinerja ilmiah siswa dari siklus I ke siklus II. Pada saat siklus I nilai rata-rata yang diperoleh 86,32 dengan standar deviasi 7,5 sedangkan pada siklus II nilai rata-rata diperoleh 87,90 dengan standar deviasi sebesar 2,5. Jika nilai rata-rata kinerja ilmiah siswa dari hasil observasi pada siklus II dibandingkan dengan standar ketuntasan hasil belajar fisika di SMK Negeri 3 Singaraja maka nilai tersebut sudah memenuhi KKM . Hal tersebut menunjukkan bahwa penelitian ini tel- 
ah mencapai kriteria keberhasilan dalam meningkatkan kinerja ilmiah siswa kelas XI TKB 2. Sedangkan untuk perbandingan nilai hasil belajar siklus I, dan siklus II disajikan pada tabel 12 .

Tabel 12 Perbandingan Nilai Hasil Belajar Siklus I dan Siklus II

\begin{tabular}{|l|c|c|}
\multirow{1}{*}{ Deskripsi } & \multicolumn{2}{c|}{ Hasil Belajar } \\
\cline { 2 - 3 } & Siklus I & Siklus II \\
\hline Nilai Rata-Rata & 73,0 & 77,5 \\
\hline Standar Deviasi & 3,1 & 1,4 \\
\hline
\end{tabular}

Berdasarkan tabel 12 diatas menunjukan adanya peningkatan nilai rata-rata hasil belajar fisika siswa dari siklus I, ke siklus II. Peningkatan rata-rata hasil belajar fisika siswa dari siklus I diperoleh nilai rata-rata sebesar 73,0 dengan standar deviasi 3,1 dan nilai rata-rata hasil belajar siswa untuk siklus II adalah sebesar 77,5. Penelitian ini sudah memenuhi kriteria keberhasilan yang sudah ditetapkan, yaitu 75 untuk meningkatkan hasil belajar siswa. Hal ini berarti model pembelajaran contextual teaching and learning yang diterapkan pada siklus I dan siklus II sudah mampu memfasilitasi perkembangan kemampuan kinerja ilmiah siswa. Pelaksanaan pembelajaran melalui sintaks model pembelajaran contextual teaching and learning yang sistematis ternyata mampu mengembangkan kemampuan kinerja ilmiah siswa yang meliputi: 1) kemampuan merumuskan masalah, membuat hipotesis, tujuan praktikum dan menetapkan langkah kerja, 2) kemampuan menggunakan alat dan bahan praktikum, melakukan pengamatan, membuat kesimpulan data hasil praktikum dan kerjasama dalam kelompok, 3) Keterampilan melakukan presentasi dan diskusi, 4) kerjasama dalam kelompok, 5) kemampuan menarik kesimpulan serta pembuatan laporan secara tertulis dan membuat kesimpulan.

\section{PENUTUP}

\section{A. Kesimpulan}

Berdasarkan rumusan masalah, hasil penelitian, serta pembahasan, maka dapat disimpulkan beberapa hal sebagai berikut:

1) Penerapan model pembelajaran contextual teaching and learning dalam pembelajaran fisika dapat meningkatkan kinerja ilmiah siswa kelas XI TKB 2 di SMK Negeri 3 Singaraja tahun pelajaran 2013/2014. Hal ini dapat dilihat dari peningkatan nilai rata-rata kinerja ilmiah yang dicapai siswa. Pada siklus I nilai rata-rata yang dicapai siswa adalah sebesar 77,37 dengan kategori cukup tinggi. Pada siklus II nilai rata-rata kinerja ilmiah siswa meningkat menjadi 87,9 dengan kategori sangat tinggi.

2) Penerapan model pembelajaran contextual teaching and learning dalam pembelajaran fisika dapat meningkatkan hasil belajar fisika siswa kelas XI TKB 2 di SMK Negeri 3 Singaraja tahun pelajaran 2013/2014. Hal ini dapat dijustifikasi berdasarkan peningkatan nilai rata-rata hasil belajar fisika siswa. Pada siklus I nilai rata-rata hasil belajar yang dicapai siswa adalah sebesar sebesar 73,0. Pada siklus II nilai rata-rata hasil belajar meningkat menjadi 77,5 .

3) Tanggapan siswa kelas XI TKB 2 di SMK Negeri 3 Singaraja tahun pelajaran 2013/2014 terhadap penerapan model pembelajaran CTL dalam pembelajaran fisika adalah berada pada kategori positif dengan skor rata-rata 39,3 .

\section{B. Saran}

Dari hasil penelitian dan temuantemuan dalam penelitian ini maka dapat disampaikan beberapa saran sebagai berikut:

1) Model pembelajaran contextual teaching and learning dapat dijadikan altrnatif pilihan dalam mengembangkan kemampuan kinerja ilmiah dan hasil belajar fisika siswa terhadap konsep-konsep fisika. Model pembelajaran contextual teaching and learning memberikan pengalaman langsung kepada siswa untuk mengenal lebih dekat alam sekitarnya.

2) Bagi guru atau peneliti yang akan menerapkan penelitian tindakan kelas dengan menggunakan model pembelajaran contextual teaching and learning disarankan untuk memperhatikan sarana dan prasarana penunjang pembelajaran demi lancarnya proses pembelajaran. 
3) Bagi guru disarankan menggunakan Model pembelajaran contextual teaching and learning berdampak pada kemandirian belajar siswa dan menjadikan siswa tidak termotivasi untuk membuat tugas-tugas yang diberikan.

\section{DAFTAR PUSTAKA}

Johnson E B. 2011. CTL (Contextual Teaching And Learning). Buku Ajar. Jakarta: Perpustakaan Nasional.

Mulyasa. 2006. Kurikulum tingkat satuan pendidikan. Bandung: PT Remaja Rosdakarya.

Nurfilah, N. 2009. Penerapan model contextual teaching and learning (CTL) dengan menggunakan metode eksperimen sebagai upaya untuk meningkatkan prestasi bela- jar dan kinerja siswa tentang suhu dan kalor kelas $X$ di sman 1 luragung kabupaten kuningan tahun ajaran 2008/2009. Skripsi. Yogyakarta: Universitas Ahmad Dahlan.

Santyasa, I W. 2006b. Pembelajaran inovatif: model kolaboratif, basis proyek, dan orientasi NOS. Makalah. Disajikan dalam Seminar di Sekolah Menengah Atas (SMA) Negeri 2 Semarapura Tanggal 27 Desember 2006, di Semarapura.

Suastra, I W. 2009. Pembelajaran sains terkini: Mendekatkan siswa dengan lingkungan alamiah dan sosial budaya. Singaraja: Universitas Pendidikan Ganesha.

Usman, M U. 1999. Menjadi guru profesional. Bandung: Remaja Rosdakarya. 